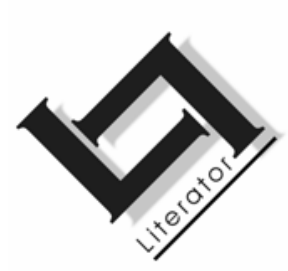

\title{
Between freedom and self-subjection: the dilemma of writing in an African language
}

\author{
Nhlanhla Maake \\ North-West University \\ Vaal Triangle campus \\ VANDERBIJLPARK
}

E-mail: nhlanhla.maake@nwu.ac.za

\begin{abstract}
Between freedom and self-subjection: the dilemma of writing in an African language

This article is an analysis of the dilemmas that confront an author who chooses to write in an African language. (Language choice remains a particularly vexing issue in African literature.) On the one hand a language that he is a master of gives him the freedom to assert himself and oppose the imperial way of thinking, which is liberating. On the other hand choice of language confines his work to a specific audience and a particular set of literary canons. Sometimes certain influential gatekeepers overtly prescribe boundaries and limit the possibilities of transcending them. On the other hand, as a case study of Sesotho literature shows, the literature itself manifests generic and thematic propensities that limit the freedom of literary expression. From the subjective and privileged position of being a writer in Sesotho himself the author in the end makes a number of suggestions on how to overcome this stifling status quo.
\end{abstract}

\section{Opsomming}

Tussen vryheid en selfonderwerping: die dilemma van skryf in 'n Afrikataal

Hierdie artikel is 'n analise van die dilemmas waarmee 'n skrywer te kampe het wat kies om in 'n Afrikataal te skryf. (Taalkeuse bly 'n onopgeloste kwessie in Afrikaliteratuur.) Enersyds gee die taal wat hy beheers hom die vryheid om homself te bevestig en die imperiale manier van dink teen te staan, en dit is bevrydend. Andersyds beperk sy taalkeuse hom tot 'n spesifieke gehoor en 'n 
spesifieke stel literêre kanons. Soms skryf invloedryke hekwagters sekere grense voor en beperk die moontlikhede om daardie grense te oorskry. Andersyds, soos 'n gevallestudie van Sotholiteratuur aantoon, toon 'n letterkunde self sekere generiese en tematiese voorkeure wat die vryheid van literêre ekspressie beperk. Uit die subjektiewe en bevoorregte posisie dat hy self 'n skrywer in Sotho is, maak die outeur ten slotte 'n aantal voorstelle oor hoe hierdie beperkende status quo oorkom kan word.

\section{Introduction}

Fiction writing is arguably the only area of écriture (act of writing) that transcends personal, class, social, spatial, temporal and cultural boundaries of identity. It also obliterates the boundaries between the imaginary and the real through different narrative techniques that can vacillate between social realism and magic realism. However, this privileged facility is, to a great extent, circumscribed by the writer's choice of language. This is an inevitable fact that language on the one hand paradoxically is a vehicle of self-assertion that enables various narrative perspectives of different authorities, moving a diversity of characters across different landscapes. On the other hand choice of language simultaneously restricts the number of possible worlds that the writer is able to conceive, and thereby limits interchange and hybridity by anchoring consciousness in the parochial universe of a specific language.

It is plausible to expect that post-apartheid South African literature would seek to challenge, interrogate and stretch the boundaries of former identities. This can only happen if writers are able to move their characters, physically or figuratively, across geographical and historical landscapes and boundaries. This process thoroughly depends on language, but, at the same time, the idea of "language" seems to narrow the possibilities of crossing boundaries. ${ }^{1}$

Language, especially given its canonical employment in literature, is intrinsically and by nature a provincial territorial marker, which tends to limit the expansion of boundaries, especially in but not exclusively to the novel. Language is the point that determines perspectives of "the other" or the "other's territory", into whose space the character ventures to travel, in order to reach out to other peoples or to explore new spaces beyond one's individual or collective marked

1 By language we are referring to human expression in all oral forms, ranging down to dialects and idiolects - any form of human expression through chosen and shared meaningful sounds. 
world, out of curiosity or to challenge or obliterate boundaries of identity; in other words, to forge hybridity.

Choosing a language to write in paradoxically is both an act of sovereign self-assertion and one of self-subjection and unfreedom. One therefore needs to consider the ways in which literature written in a particular language can negotiate this self-subjection and assert the freedom of the writer.

\section{The paradox of self-subjection and the assertion of freedom}

A conscious decision to negotiate with the world through a language in which one is competent makes one the supreme master of one's narrative. You are centring yourself as the gazing/observing agent who creates, re-creates, discovers and narrates. In narrating one interprets the world by establishing an imperial position over the world. You appropriate omniscience through the universal authority that narrative technique grants you. You are free to expand the horizon of gaze through omniscience or narrator-protagonism, or narrow it through direct observation, or I-narration.

Choice of language also means that you speak of, to and for a particular group, even a marginalized group in terms of the South African language status quo. Yet at the same time you sacrifice and marginalise yourself by excluding those who are not privy to that particular language and thereby restricting your potential audience.

Choosing a language can mean self-empowerment if this enables you to choose a narrative mode of realism or magical realism that transcends physical boundaries, collapses the polarities between the physical and metaphysical, and negotiates the contradiction between the pure and the hybrid.

Even if one, through the authority of narrating, were to be in many places at the same time (solidity of action), one has to narrate one place at a time (linearity of narrative). Limitation of the scope of narrative freedom to attempt to challenge the boundaries imposed by "linearity of narrative" as opposed to solidity of action in writing would be a nihilistic exercise, enforced by the nature of the written medium itself. This problem can only be overcome by the audiovisual medium (film) but not by means of language.

Language is a vehicle and locus of and for negotiating with the world; it instils consciousness (Fanon's "collective consciousness"), 
and creates "others". Choosing a non-imperial language would therefore mean seeing the world from a different (and more limited) position than the one determined by the world view created by the imperial language. The counter-hegemony of the "empire writing back" (Ashcroft et al., 1989) did not travel into imperial space in order to extend itself by seeing the imperial with its own eyes. Its gazing eye/l saw the world from its own position, even when it travelled to the metropolitan centre, subverting the perspective of the imperial eye. In Things fall apart Achebe (1965) deals with imperialism by justifying and explaining the lgbo world in relation to a culture/religion that is slowly but inexorably invading it. There is no outward tropism in his gaze as he does not move out of the Igbo cosmos, as Haggard and other Victorians moved out of their world. Perhaps aware of the need to challenge the metropolis in its own territory, the most radical of all African writers, Semebene Ousmane, wrote, amongst other works, The black girl, the story of a Senegalese girl who travels to France and gazes at the metropolis from inside, rather than seeing the imperial metropolis from outside, from a static position.

We are referring to examples in Anglophone literature because I do not know of any African language text where the gazing eye/l migrates from its own centre to another position. Ousmane broke away from the tradition of seeing the European travelling to the colony, and also the idea that only men travel over to the metropolis. In The black girl we see France through the gazing eye/l of a young Senegalese woman, whereas in other works of the "been-to" motif we only see travellers when they return home. In a number of works the gaze of the metropolitan centre is strengthened by moving from the exiled and colonial culture of the metropolis into the microcosm of the colonial homestead, such as in The grass is singing. But it is Doris Lessing who broke the barriers and adopted an omniscient perspective that few men dared to do in her time. Lessing made her transcending protagonist a woman, in the same way as Karen Blixen, who also broke boundaries by liberating her eye/l from colonial experience.

Choosing a language also means choosing a literary tradition. This entails a self-initiation and baptism into a canonised space called literature. 2 Traversing the canonised space, for better or for worse,

2 We are using canonised in both the secular and the spiritual sense, which both encompass the idea of placing oneself above others or on a higher pedestal, where rules of narrative are not infinite, as compared to theatre and film. 
dictates a degree of rupture from the oral tradition. The literature produced removed or shifted the speaking word from the general populace, where participation was a communal rather than an individual act. I do not want to suggest that this was wrong, but I have to admit that individualism is inherent to the industrial system. The learned African, in challenging the hegemony of the empire in narrative, was totally aware of this, but perhaps he (we are using the male pronoun advisedly) first had to learn to initiate himself into the sacraments of the Western genres. It was Amos Tutuola who unintentionally subverted the tradition and canon in his My journey in the bush of ghosts, The palm wine drunkard, and A complete gentleman. His surrealism, magical realism and "new English" was innovative par excellence, even though some critics, at a loss for critical tools to deal with him, attributed this to derivation from the folk narrative tradition.

To opt for a particular language also implies a circumscription of your primary audience since your are addressing one "imagined" community which has been initiated and educated into a particular world view through that language. You also limit your audience by choosing literature as your vehicle in the post-modern plethora of competing media - television, theatre, radio, printed and electronic media. Here the paradox becomes even more apparent. On the one hand you are negotiating for and on behalf of the particular worldview and the particular historical baggage embodied in that language. At the same time you are limiting the authority or centrality of your position by engaging in a discourse which loops like a snake biting its own tail - in a language they cannot understand (or do not care to understand for that matter) no "others" are challenged.

The writers who adopted the language of the metropolis were aware of the challenges they faced, as Mphahlele (1962) said: "Those of us who write in the metropolitan languages know that we have abandoned the direct route leading from tradition, which is the mother tongue, for the most intricate and perilous one of interpreting in a language and genre that belongs to a historical tradition outside our own origin. It is a perilous commitment ... another peril lies in the fact that we have to be judged in terms of the tradition in which we write." This was not to be for Tutuola.

As far as Ngugi wa Thiong'o is concerned the path is even more perilous if one writes in English at the expense of leaving his or her immediate community behind. For Achebe the solution lay in transgressing the prescriptions of the metropolitan language, but 
here is a counter-argument by an Africanist journalist: "It is sickening reading Achebe defending English as our lingua franca ... their books are, commercially speaking necessarily written in English" (Achebe, 1974:87). That was a response to Achebe's statement: "Those African writers who have chosen to write in English are not smart alecs with their main chance outside their community. They are by-products of the same process that made [created] the new states of Africa" (Achebe, 1974:57). As far as Achebe is concerned English is the only vehicle that will allow him to transcend the boundaries of ethnicity and narrow Afrocentrism. He writes that colonialism "did bring together many people that had hitherto gone their several ways. And it gave them a tongue, with which to sigh" and continues, "but for me there is no other choice, I have been given this language, and I intend to use it" (Achebe, 1974:58-62).

In 1989, when I was a Visiting Fellow at Yale University, I spent many hours with Ngugi in a restaurant on Broadway Street, sipping tea right into the early hours of the morning. Our conversations and a thorough interrogation of his views convinced me that he was right, in that his position was so well defended that I could not gainsay it, more so that I needed no convincing even from the outset. Mothobi Mutloatse once suggested that the way out of the trap is that "[t]he writer has to make the all-important decision: which comes first - one's home audience or the world at large (which is remote). Inevitably he has to opt for the home audience first" (Mutloatse, 1980:2). And on the method of reaching this aim he says:

We will donder conventional literature: old fashioned critic and reader alike. We are going to pee, spit and shit on literary convention before we are through; we are going to kick and push and pull and drag literature into the form we prefer. We are going to experiment and probe and not give a damn what the critics have to say. Because we are in search of ourselves undergoing self-discovery as a people (Mutloatse, 1980:5).

Perhaps one should acknowledge that choosing a language will remain a dilemma. The deliberate adoption of English in the Anglophone world as a medium of creativity was meant to be a vehicle for addressing the metropolitan audience about the plight of the colonial world. Once again we see the writer breaking with his African community, except of course for a few upwardly mobile and educated Africans. The contradiction did not go without notice or awareness, as a debate on what is African literature raged from the 1960s, initiated by a Nigerian journalist called Obi Wali: 
The whole acceptance of English and French as the inevitable medium of educated African writing is misdirected and has no chance of advancing African literature and culture. In other words, until those writers and their mid-wives accept the fact that any true African literature has to be written in African languages, they would be merely pursuing a dead end, which can lead only to sterility, uncreativity, and frustration (Wali in Ngugi wa thiong'o, 1981:56).

Soyinka, Achebe, Ngugi, Mphahlele, and Nkosi joined the debate, and later the intractable Chinuweuzu. In South Africa the generation who later started writing in African languages and in English also entered the fray. Notable among these are the Dhlomo brothers, R.R.R. DHlomo and H.I.E. Dhlomo, who wrote exclusively in (isi)Zulu and English respectively.

The debate has continued ever since, but what is interesting is that those who write in English are now stridently in favour of writing in other languages, especially since the Asmara Declaration, which unapologetically advocated the promotion of African languages, not only in creative writing but also in other spheres of life. A case to illustrate this is the BUWA Conference which was held at the Sheraton Hotel in Pretoria on 16 September 2003. The theme was "African Languages and Literatures". What surprised me pleasantly was the Conference's unequivocal advocacy of the promotion of writing and reading literature written in African languages, but at the same time I could not help being amused by the fact that I was the only writer invited who indeed writes in an African language.

Let me elaborate on the question of entering into canonised spaces so that I can demonstrate what the paradox of language choice and the fixity of boundaries of identity mean in practice. In order to engage as a writer, one has to enter the defined space of literature. In South African literature we have boundaries that mirror the inevitable choice or imposition of language, namely African language literatures that encompass nine official languages, Afrikaans literature, and English literature, derived, to a great extent, from British English literature. Unless one is competent in all these languages, you are always limited to speaking to a specific community and remaining within the boundaries of the community who speak the language of your choice. There are very few writers who write professionally in more than one language. One can think of André Brink and Antjie Krog, who write in both English and Afrikaans, but there is no one who writes in two African languages even though there are many writers who are multilingual. This can 
be attributed to narrow ethnicity or nationalism, which expressly prohibits hybridity in any form. These concepts coincide with language identity. In Sesotho, (isi)Ndebele and (Se)tswana ethnicity, nationalism and language identity only partly coincide, in that above or coincident with cultural identity, two nation states have contesting claims upon a national identity. That is the base, but the superstructure as determined by narrow-minded nationalists is dictated by unwritten but de facto laws. This territorial imperative manifests itself even in the translation of literary works. Mofolo's classic has been translated into Afrikaans, English, French and German, but in no other South African Bantu language.

One therefore has to conclude that the choice of language is a trap into which you weave yourself. In Sesotho literature this is very strongly the case, because of the conservatism of the incestuous Sesotho academic fraternity. They dictate that Sesotho literature must speak pure Sesotho and confine itself to certain narrative forms which are clearly defined - experimenting with surrealism in the novel, the theatre of the absurd in drama, and the avant-garde in the essay is strictly forbidden (and you transgress this prohibition at your peril). They do not define what pure (Se)sotho is, but it is easy to see through the thin veil that it means writing in the dominant dialect. Despite the availability or translators (who are able to open the jaws of the trap), the tension between self-empowerment and a fixed identity persists. The question is how to break out of this parochial prison.

\section{Gazing at the other in Sesotho literature}

The first Sesotho novels, written by pioneers who are very difficult to emulate, were travel novels. Segoete's Monono ke Mohodi ke Mouwane (Pleasure is but mist and vapour) was then followed by Mofolo's Moeti wa Bochabela, which was translated as Traveller to the East. I reread them with the rather queer eye of trying to find out how the travellers break the boundaries of space and reveal to the Mosotho reader of the time how the "other" lived and how he engaged with foreign landscapes. Mofolo's narrative, which is based on the motif of The pilgrim's progress, was disappointing. As I followed the quest of the protagonist, Fekisi, I looked for the challenge of the gaze, that is, how Fekisi perceived the people through whose lands he travelled, who were different from his own folk. Fekisi travels to the East in quest for everlasting peace, and like all pilgrims, he encounters challenges which he has to overcome, presented by both beast and man, but he eludes my interrogation of his gaze because the other people that Fekisi meets belong to 
fictitious imagined communities. We are not suggesting that being realistic would have solved my problem, but that I was failing to make any progress in testing my hypothesis.

Segoete's work came close to relieving me of my anxiety, as his protagonist, Khitshane, is a picaro who travels through recognisable places in South Africa, meeting with recognisable population groups. He travels from Lesotho through the rural and urban landscapes of South Africa, landing in jail once or twice. Without going into the details of his journey, suffice it to say that the travels of the protagonist transcend the confines of space. The author's experimentation with narrative perspective and free use of magical realism (that goes against the realist norm in Sesotho literature) empowers the narrator and tests the boundaries of the Sesotho lifeworld.

As far as the novel is concerned there seems to be only three narratives where the Sesotho readers find an opportunity to travel with the gazing eye/l of the protagonist, namely the two aforementioned novels, and Maphalla's Kabelwamanong (One destined for vultures). The latter is a younger writer of the 1980s and 1990s; he is still productive. His protagonist (after whom the book is named) travels outside the national borders of his country. He, like Mofolo's Fekisi, puts my thesis to a serious test, because the landscape which his protagonist traverses is populated by characters who are explored only in terms of action but not depth, and one loses the "otherness", even though some of their names suggest that they may be placed on the South African map.

In my frustration with the novel, I sought further support for my hypothesis in the work of one of the Basotho's greatest poets ever, Kemuele Ntsane, who is the only writer capable of satire in the language. He is also a novelist of considerable standing, but his forte is poetry. An overview of his two anthologies, Mmusapelo I and Mmusapelo II (1946) (Heart restorer I and II) shows that he clearly beaks the bounds of a static gaze. Ntsane is a master of narrative poetry and does not limit the scope of his characters' travels. I can only describe his persona's travels, and it is a pity that I cannot emulate the texture of his satirical tone (again the trap of language choice). In "Ha re ya Lejweleputswa" (When we go to the Rand) Ntsane follows a number of mine recruits who are travelling from Lesotho to the South African mines. We see them preparing for the journey the night before. The first-person protagonist in the poem appropriates the point of view of the group for himself: 
Ra lala re phehile mofaho ka la maobane Merwalo re e tlamme ntjha tsa batho, Ntja tsa moreneng ma-lala-a-laotswe. Laola morena re lokile,

We prepared our provisions the night before

Our baggage was tied and ready like dogs of the road

Dogs of war, ever ready

Ready to take the commands of our boss

Ready to crawl into the holes of mice,

Ntsane's tone of voice is satirical, in that it treats a serious subject in a light-hearted manner. The persona speaks as if the journey to the mine was voluntary, and words such as "ntja tsa batho" ironically reinforces a sense of willing readiness and enthusiasm for the journey. In this regard Ntsane uses irony as a satirical device. As we travel with them, we see how they are treated harshly by officials at the recruitment office. Some of them cannot even sign their names on the forms, let alone read: "Ra saena tshu re sa mo tsebe" (We even signed ' $q$ ', despite the fact that we did not know it). The persona is lampooning his own illiteracy, under circumstances which are serious and do not call for laughter.

In Hwenene (Home brewed sorghum beer) a rogue husband goes to a tavern on a drinking spree. From the first-person point of view he tells how he pulled out a five-pence coin from his pocket and ordered a round of beer, and boasts to the shebeen queen that she can keep the change. After some self-praising, in the tone of praise poetry, he walks home very drunk, and along the way he urinates against a wall, only to see another fellow drunkard doing the same. By the time he gets home he is almost crawling. His wife attacks him with a cooking ladle and throws pot lids at him. The next day when he wakes up, he has a heavy hangover, and as he relives the night before, he is stricken with contrition. When the drunken character praises his prowess in drinking, the tone of voice adopted is that of heroic poetry, which reveals the sharp contrast between acts of heroism and drinking.

In Keiting ya Dihele (At the gates of hell) Ntsane takes us to the gates of hell, where the condemned are waiting in a queue, each hoping that his name would not be in the register of those who have to enter through the gates of hell. Ntsane's is at his best with his satire. In the narrative poem we see people shoving and pushing each other out of the way, in the belief that they are standing at the gates of heaven, whereas they are at hell's gates. Among them we see a minister of religion who cuts the queue and goes right up to 
the head of the queue. When he gets there indeed his name is there, but little does he know that he is entering hell instead of heaven. The satirical mood of the poem is sustained by the fact that the reader knows whether the characters are, and knows what they are going to discover when they reach the gate. Ntsane presents them in such a melodramatic manner that they become caricatures.

Even Ntsane's stretching of boundaries is limited, since the persona narrates journeys that only cross class boundaries to a great extent only within the Basotho society. We reread other works of South African Sesotho writers, but found no travelling protagonist who transcends the boundaries of his territory.

Whether it is by dictates of segregation of the peoples of South Africa by apartheid, or purely by the choice of language, or a combination of the two, it seems that stretching boundaries and thereby phasing them out, is a reality which seems to elude us writers in African languages. Perhaps this finding also applies to writing in other South African languages, that is, English and Afrikaans. When coming to post-1994 works in Sesotho, I have read a few, e.g. N.S. Zulu's Nonyana ya Tshepo (Bird of hope) (1997) and T.W.D. Mohapi's Lehlaba la Lephako (Pangs of hunger) (1999), both of which deal with master-servant relations on farms. In these narratives again no character ventures outside the boundaries of his or her community or cultural group.

We do not want to appear prescriptive by suggesting that the literature should take a particular direction, like the current tyrants of critics who dictate norms are doing. I rather seek to find out whether the political changes of the new South African democracy have opened up opportunities for writers who write in African languages to interrogate the boundaries of the past, critique the social changes that have been born of this democracy, and many other aspects which were introduced by the new dispensation. We still have to see Basotho children going to school with other children. Our travellers, even if they are rogues, still have to cross the borders of their own territories in order to give us a glimpse of the "other", or the "other" that has become part of us.

Perhaps one limitation is that autobiographical and biographical works, both real and fictional, do not exist in African languages, except for early ones such as Mqhayi's in (isi)Xhosa, and R.R.R. Dhlomo's lives of Zulu kings of the nineteenth century. The auto/biography and travelogue seem to be the main genres that offer the writer opportunities to go beyond the boundaries, as is 
evident in other languages. I still have not come across Sesotho narratives that cross into other terrains. Even novels like Itshwele Lempangele (Guinea-fowl chicken) (Bhengu 1998) do not qualify for even though it deals with problems of marriage across the racial line, the societies whose antagonistic positions are portrayed remain in their cultural locus. As a result the reader sees them opposing each other from a static position, without moving out of their own territory.

A survey of "safari", (ki)Swahili for "journey", or travel novels was undertaken by Moeketsi and Zulu (2003), in which they studied "the influence and relationship of space and character portrayal in the Sesotho novel". In this important study the authors selected about a dozen Sesotho novels and analysed the travelling protagonists. Unfortunately their study does not go beyond studying the travelling protagonists in terms of the types of space through which they travel or in which they settle and the influence that the space exerts on them. They do not venture into the characters' interaction with the populace of that space, especially those who are different from them. This study does not directly address my hypothesis, but what can be drawn from it is that in these Sesotho novels there is an obvious absence of engagement with the "other", which suggests an inward looking mindset.

\section{Breaking the shackles of this inward-looking tropism}

In this discussion we adopt our working definition of tropism, which we borrow from the lexicon of Botany, to refer to movement towards figuratively light, that is, in a positive direction toward unlimited growth.

We return to the question of breaking out of the trap of language choice. In English there are several biographies and autobiographies that challenge boundaries, notably the Mandela auto/biographies. They reveal a long walk from a rural background, with a settled worldview that made him at some point in his political career in the Youth League advocate of the exclusion of white people, up to the evolution of his mature political outlook. Auto/biographies are creative works. Another example is the biography of Bram Fischer (Clingman, 1998), which takes the reader through his journey from a narrow nationalist view of life and the "other" to a complete metanoia. We find similar journeys in the narratives of Rian Malan (Malan, 1990) and others. We are not suggesting that the genre which can liberate African languages writers is the auto/biography, but we are simply stating that writing 
auto/biographies might be one of the ways out of the dilemma of language choice.

We hesitate to make a further suggestion, as I also write in Sesotho, which is not my mother tongue. To suggest that we need to liberate ourselves from the shackles of purity of language is to put myself in line for ostracism, yet I think that might be a second way out of this trap. The idea of purity of language, which prescribes that the only acceptable form of Sesotho is that which is spoken in the Free State or by people who originate from there or the former Homeland of Qwaqwa, sounds like a retreat to the laager of narrow ethnicity. This will keep the self-asserting eye/l forever myopic. What is ironic in this regard is that in Lesotho the perception of purity of language in fiction seems to be more liberal. Perhaps this is partly the result of Ntsane, who took liberties with the Sesotho lexicon. In the history of English literature we saw how the Americans disregarded the mainstream of (British) English literary style and established one of the major traditions of the Englishes of the world, producing masterpieces of travel writing like The adventures of Huckleberry Finn. The Caribbean writers followed them in this revolution, producing a Nobel Laureate who wrote in their English dialect, e.g. Derek Walcott.

My third suggestion on how we should transcend physical and cultural boundaries in our creative writing, and this might sound radical, is that we have to adopt a language register and code which will reflect the changed times. We have perhaps to break the bonds of monolingualism in our writing and free our characters. Ngugi objected to peasant characters being made to speak broken English in Anglophone literature, and in his novels he made them speak Standard English. I would suggest that when characters in our creative works cross boundaries, they must be liberated to speak the language of the "other", within a predominant language. Am I suggesting code switching and code-mixing, which is tantamount to anarchy? I see no other way to escape the trap in which language ensnares us. Let our characters break down the linguistic, temporal and spatial Berlin walls of censorship.

An even greater challenge is that South Africans should acquire multilingual literacy. Let us also liberate our potential by mediating our texts through translations in all directions across South African language barriers. But as long as our characters are static and negotiate only familiar territory, then we may lose the interest of the "others". Our theatre has gone a long way in doing this. In the 1970s Welcome Msomi produced Shakespeare's Macbeth in isiZulu, and it 
received acclaim even by the most conservative British critics on their home ground. Plays like Sophiatown and adaptations of Modikwe Dikobe's Marabi dance did it in the 1980s. Credo Mutwa's great classic, Unosilimela, did it in the 1970s.

Tutuola shifted the boundaries of both English and realism. What we are saying is that there are enough opportunities for post-1994 literature in African languages similarly to transcend barriers of language and content. How to balance on the tightrope between globalisation and parochialism is a question to which I cannot find an easy answer, but suffice it to suggest that globalisation can only be facilitated by a good grounding in the local. How one can move from the local to the global through languages which are subjected to local dictatorships, over and above being circumscribed by geographical space and use, is a question that I cannot answer yet.

\section{List of references}

ACHEBE, C. 1965. Things fall apart. London: Heinemann.

ACHEBE, C. 1974. Arrow of God. London: Heinemann.

ASHCROFT, G., GRIFFITHS, G. \& TIFFIN, H. 1989. The empire writes back: theory and practice in post-colonial literatures. London: Routledge.

CLINGMAN, S. 1998. Bram Fischer Afrikaner revolutionary. Cape Town: David Philip.

MALAN, R. 1990. My traitor's heart. New York: Grove.

MOEKETSI, S.M. \& ZULU, N.S. 2003. The literary history of space and character in the Sesotho novel. South African Journal of African Languages, 23(2):95-110.

MPHAHLELE, E. 1962. African image. London: Faber \& Faber. MUTLOATSE, M. 1980. Forced landing. Johannesburg: Ravan.

NGUGI WA THIONG'O. 1981. Writers in politics. Heinemann: London.

NTSANE, K.E. 1946. Mmusapelo I. Morija: Morija Book Depot.

NTSANE, K.E. 1946. Mmusapelo II. Morija: Bona Press.

\section{Key concepts:}

African literature - choice of language

overcoming the parochialism of literary traditions

Sotho-literature - representations of the other

travel writing

\section{Kernbegrippe:}

Afrikaliteratuur - taalkeuse

deurbreking van die parogialisme van literêre tradisies

reisliteratuur

Sotho-literatuur - uitbeelding van die ander 